\title{
Role of cytokines in pregnant women with chronic iron deficiency anemia in preeclampsia pathogenesis
}

\section{Summary}

The frequency of development of hypertensive states in IDA reaches $32-45 \%$. The pathogenesis of the combined complications of pregnancy with anemia and preeclampsia, including immunological aspects has been little studied.

Purpose: to clarify the role of violations general and local cytokine status in pregnant women with anemia in the genesis of preeclampsia and justify the need to include immuno suppressants for the prevention and treatment of preeclampsia.

Materials and methods: In 96 pregnant women with iron deficiency anemia (IDA) and preeclampsia in the third trimester of gestation the cytokine status of IL-1 $\beta$, IL-6, IL$8, \mathrm{TNF} \alpha$ and lactoferrin in the serum of peripheral blood and in extracts of the placenta decidual tissue was examined by ELISA. Pregnant women were divided into 4 groups: 24with mild anemia, 18-with moderate anemia, 26-with preeclampsia and with mild anemia and 28 pregnant women with preeclampsia and with moderate anemia.

Results: It has been established that preeclampsia on the background of IDA is accompanied by a significant increase in the level of pro-inflammatory cytokines $(p<0,05)$ and the acute phase protein lactoferrin $(p<0,05)$ on the systemic and to a greater extent on the local level in the development of preeclampsia on the background of anemia of moderate severity $(p<0,05)$.

Discussion: The data obtained confirm the involvement of the immune system in the pathogenesis of preeclampsia, one of the trigger mechanisms of which is the immune imbalance in iron deficiency anemia. A pathogenetic rationale for the use of immunosuppressive therapy for combined pathology is given.

Conclusion: The use of placental hormone - progesterone as an immunosuppressive drug in terms of substantiating new immunotherapy strategies for the prevention of preeclampsia is a topical trend in obstetric practice.

Keywords: preeclampsia, iron deficiency anemia, cytokines, immuno correction
Volume II Issue 3 - 2020

\author{
Djabbarova Yu K,' Ismoilova Sh T, \\ Musakhodzhayeva $\mathrm{DA}^{3}$ \\ 'Republican perinatal center of the Ministry of Health, Tashkent, \\ Republic of Uzbekistan, Uzbekistan \\ ${ }^{2}$ Fergana Medical association, Fergana, Republic of Uzbekistan, \\ Uzbekistan \\ ${ }^{3}$ Institute of immunology and genomics of human in Academy of \\ Sciences, Tashkent, Republic of Uzbekistan, Uzbekistan
}

Correspondence: Dzhabbarova Yu K, Republican perinatal center of the Ministry of Health, Tashkent, Republic of Uzbekistan, Tashkent D.Abidova St. 223, Uzbekistan, Tel+998946996402, Email ulduzjab43@mail.ru

Received: April II, 2020 | Published: May 22, 2020
Abbreviations: IDA, iron deficiency anemia; HB, hemoglobin; DT, decidual tissue; EC, natural killer cells, IL, interleukin; TNF, tumor necrosis factor

\section{Introduction}

In practical obstetrics, the problem of iron deficiency anemia (IDA) in pregnant women and puerperal remains very relevant. Worldwide, the frequency of anemia in pregnant women ranges from $25 \%$ to $50 \%$, in developing countries - from $35 \%$ to $75 \%$, in developed countries is $18 \%-20 \%{ }^{1,2}$ The average rate of anemia in the Russian Federation reaches $32 \% .{ }^{3}$ In residents of the Central Asian republics, pregnancy in most cases proceeds against the background of IDA. Thus, the prevalence of IDA among women of reproductive age has decreased in the last 12 years from $60 \%$ (1996) to $33.5 \%$ (2008) in Uzbekistan. ${ }^{4}$ It is well known that anemia aggravates pregnancy and childbirth, due to iron deficiency and chronic hypoxia, which negatively affect the mother's body, contribute to the development of preeclampsia, miscarriage, weakness of labor, premature detachment of a normally located placenta, bleeding in the postpartum period, postpartum septic diseases, perinatal, complications. ${ }^{5,6}$
Based on the analysis of literature data V.E. Radzinsky et al. ${ }^{6}$ indicate that a violation of the course of gestation occurs as a result of the fact that with severe anemia there is no transformation of the spiral arteries, their smooth muscle layer is preserved, but does not disappear, as is the case with normal pregnancy. The result is increased fetal hypoxia - fetoplacental insufficiency, since not expanding spiral arteries are not able to provide the growing demand for blood supply. It is these pathological processes that underlie the established relationship between anemia and miscarriage, premature detachment of a normally located placenta. In addition, these changes can increase the risk of preeclampsia, bleeding during childbirth, weak labor, postpartum septic complications..$^{7-10}$ Anemia causes circulatory and tissue hypoxia, characterized by a deficiency of protein, iron and other essential trace elements. These factors are the pathogenetic basis for the development of preeclampsia. The frequency of development of hypertensive states in IDA reaches $32-45 \% .{ }^{11}$ The combination of preeclampsia with anemia is a real threat to the life of the mother and newborn. Among women who died of preeclampsia, IDA was observed in $85.3 \%$, the frequency of preeclampsia increases with decreasing hemoglobin (HB) levels: for example, it was $11.1 \%$ with 
hemoglobin $<70 \mathrm{~g} / 1,14.5 \%$ with hemoglobin $<60 \mathrm{~g} / 1$ and $30.0 \%$ at its level $<50 \mathrm{~g} / 1 .{ }^{12}$

Preeclampsia continues to be one of the urgent problems of modern obstetrics, which is associated with a significant increase in the frequency of this pathology and a frequent adverse outcome for both the mother and the fetus; it is the main cause of perinatal morbidity and mortality. ${ }^{13,14}$ Preeclampsia develops in $6-12 \%$ of healthy pregnant women, in $20-40 \%$ of pregnant women with extragenital pathology. ${ }^{15}$ The study of issues related to this pathology remains relevant to date.

There are many theories for the development of these disorders. Most researchers came to the conclusion that there is no single mechanism for the development of preeclampsia, and there is a combined effect of etiological factors: neurogenic, hormonal, immunological, genetic, placental. To date, despite numerous studies, the pathogenesis of preeclampsia has not been fully studied. ${ }^{16,17}$ Preeclampsia as the main obstetric pathology is inherently considered at present as an immunological phenomenon. ${ }^{18}$ The development of preeclampsia is a reaction similar to rejection of an allograft and the production of various antibodies, including antiphospholipid ones. ${ }^{19} \mathrm{It}$ is believed that immune processes not only contribute to the development of preeclampsia, but also determine its severity. ${ }^{17,18,20}$

The aim of the study was to clarify the role of violations of the general and local cytokine status in pregnant women with anemia in the genesis of preeclampsia.

\section{Materials and research methods}

To clarify the role of immunological disorders in IDA in the genesis of preeclampsia, we conducted immunological studies by method of random sampling in 96 women in the third trimester of gestation. The inclusion criteria were: pregnancy in the third trimester; hypochromic microcytic anemia: $\mathrm{Hb}$ level less than $110 \mathrm{~g} / \mathrm{l}$; absence or appearance of signs of mild preeclapsia; 18 to 42 years of age; the informed consent. Exclusion criteria were: other types of anaemia, blood disease; heavy endocrinopathy; heart and vascular diseases; lesions of other organs and systems (chronic renal, hepatic failure); acute infections (AIDS, viral hepatitis, etc.).

Pregnant women were divided into 4 groups: 24-with mild anemia (HB level from 110 to 90g/1), 18-with moderate anemia (HB level from 89 to $70 \mathrm{~g} / \mathrm{l})$, 26-with preeclampsia against anemia mild and 28 pregnant with preeclampsia against moderate anemia. The cytokine status of IL-1 $\beta$, IL-6, IL-8, TNF $\alpha$ (Tumor necrosis factortumor necrosis factor) and lactoferrin in peripheral blood serum and in placental decidual tissue extracts were determined by ELISA. Pieces of decidual placental tissue (up to $3 \mathrm{~cm} \mathrm{2}$ ) were washed, dried, weighed, then homogenized, saline was added to its original weight, homogenated, after freezing $\left(-20^{\circ} \mathrm{C}\right)$ during the day, it was thawed and ultra centrifuged. The obtained supernatant was used to determine the concentration cytokines. Used reagents LLC "Cytokine" (St. Petersburg., Russia). The results obtained in pregnant women with mild anemia were used as controls. Statistical data processing included determination of the arithmetic mean and arithmetic mean errors. Significance of differences was calculated by Student $t$-test.

\section{Results}

The results of the study of the content of cytokines in the blood serum of the examined pregnant women are presented in Table 1 and in decidual tissue - in Table 2.

Table I Cytokine status and the level of lactoferin in the blood serum of pregnant women with anemia and preeclampsia, $M \pm m$

\begin{tabular}{|c|c|c|c|c|}
\hline Indicators & $\begin{array}{l}\text { Control group, } \\
n=24\end{array}$ & $\begin{array}{l}\text { Pregnant women } \\
\text { with moderate } \\
\text { anemia, } n=18\end{array}$ & $\begin{array}{l}\text { Pregnant women with } \\
\text { mild anemia, and mild } \\
\text { preeclampsia, } n=26\end{array}$ & $\begin{array}{l}\text { Pregnant women with } \\
\text { moderate anemia and mild } \\
\text { preeclampsia, } n=28\end{array}$ \\
\hline $\mathrm{IL}-\mathrm{I} \beta, \mathrm{pg} / \mathrm{ml}$ & $211,3 \pm 12,8$ & $256,1 \pm 15,9 *$ & $317,3 \pm 14,2^{* \wedge}$ & $397,9 \pm 17,9 * \wedge \mathrm{a}$ \\
\hline $\mathrm{IL}-6,, \mathrm{pg} / \mathrm{ml}$ & $87,9 \pm 8,1$ & $113,3 \pm 7,4^{*}$ & $162,2 \pm 8,5^{\wedge}$ & $219,3 \pm 9,9 * \wedge \mathrm{a}$ \\
\hline TNF- $\alpha, p g / m l$ & $59,9 \pm 3,7$ & $82,6 \pm 5,9 *$ & $86,7 \pm 5,6$ & $1 \mid 3,2 \pm 6,5^{* \wedge} \mathrm{a}$ \\
\hline IL-8, pg/ml & $36, I \pm 3,3$ & $70, I \pm 5,8^{*}$ & $94,7 \pm 5,7^{\wedge}$ & $120,8 \pm 9,2^{* \wedge} \mathrm{a}$ \\
\hline Lactoferrin, ng/ml & $1028,8 \pm 80, \mid$ & $|354| \pm 86,,6^{*}$ & $1565,5 \pm 80,3$ & $|750,9 \pm 7|, 58^{* \wedge}$ \\
\hline
\end{tabular}

Note: $*$ - the values are significant in relation to the control group, $(p<0.05),{ }^{\wedge}-$ the difference is significant in relation to moderate anemia data $(p<0.05)$, a - the difference is significant in relation to mild anemia and mild preeclampsia $(\mathrm{p}<0.05)$. IL, interleukin; TNF, tumor necrosis factor

Table 2 The cytokine status and level of lactoferin in the decidual tissue of women with anemia and preeclampsia, M $\pm m$

\begin{tabular}{|c|c|c|c|c|}
\hline Indicators & $\begin{array}{l}\text { Control } \\
\text { Group, n=24 }\end{array}$ & $\begin{array}{l}\text { Pregnant women } \\
\text { with moderate } \\
\text { anemia, } n=18\end{array}$ & $\begin{array}{l}\text { Pregnant women with } \\
\text { mild anemia, and mild } \\
\text { preeclampsia, } n=26\end{array}$ & $\begin{array}{l}\text { Pregnant women with } \\
\text { moderate anemia and mild } \\
\text { preeclampsia, } n=28\end{array}$ \\
\hline $\mathrm{IL}-\mathrm{I} \beta, \mathrm{pg} / \mathrm{ml}$ & $255,8 \pm 15,4$ & $3|7,1 \pm 2|, 7^{*}$ & $388,2 \pm 12,9 * \wedge$ & $468,7 \pm 26,3^{* \wedge} \mathrm{a}$ \\
\hline IL-6, pg/ml & $212,5 \pm 14,4$ & $263,2 \pm 19,3^{*}$ & $323,9 \pm 14,8 * \wedge$ & $437,4 \pm 25,4^{* \wedge} \mathrm{a}$ \\
\hline TNF- $\alpha, p g / m l$ & $88,7 \pm 6,2$ & I $44,2 \pm 7,2 *$ & $|2|, 4 \pm 7,4 *$ & $130,4 \pm 7,6^{*}$ \\
\hline IL-8, pg/ml & $48,5 \pm 4,3$ & $84,5 \pm 4,7^{*}$ & $|29,5 \pm 8|, * \wedge$ & $|75,8 \pm| 2,8^{* \wedge} a$ \\
\hline Lactoferrin, ng/ml & $724,9 \pm 50,3$ & $988,3 \pm 37,6^{*}$ & $|279,7 \pm 5|, 0^{* \wedge}$ & $|37|, 9 \pm 50,9 * \wedge$ \\
\hline
\end{tabular}

Note: $*_{-}$the values are significant in comparison with the control ones $(p<0.05), \wedge$ - the difference is significant in relation to the data of moderate anemia $(p<0.05)$, a - the difference is significant in relation to the data of mild anemia and mild preeclampsia $(p<0.05)$. IL, interleukin;TNF, tumor necrosis factor 
It was found that in women of the control group, the level of the cytokine IL - $1 \beta$ in decidual tissue (DT) was 1.2 times higher $(255,8 \pm 15,4 \mathrm{pg} / \mathrm{ml})$ than in blood serum $(211,3 \pm 12,8 \mathrm{pg} / \mathrm{ml}, \mathrm{p}<0.05)$, the level of TNF- $\alpha$ was 1.5 times higher $(88,7 \pm 6,2 \mathrm{pg} / \mathrm{ml}$ than $59,9 \pm 3,7 \mathrm{pg} / \mathrm{ml}, \mathrm{p}<0.05)$, IL-6-2.4 times higher than the systemic value $(212,5 \pm 14,4 \mathrm{pg} / \mathrm{ml}$ than $87,9 \pm 8,1 \mathrm{pg} / \mathrm{ml}, \mathrm{p}<0.001)$. The level of IL-8 in the blood $(36,1 \pm 3,3 \mathrm{pg} / \mathrm{ml})$ was slightly lower than the values in DT $(48,5 \pm 4,3 \mathrm{pg} / \mathrm{ml}, \mathrm{p}<0.05)$ and the level of lactoferrin in DT $(724,9 \pm 50,3 \mathrm{ng} / \mathrm{ml})$ was 1.4 times significantly lower than in blood serum $(1028,8 \pm 80,13 \mathrm{ng} / \mathrm{ml}, \mathrm{p}<0.01)$. Thus, the level of proinflammatory cytokines in the third trimester of pregnancy in serum of peripheral blood is significantly different from the synthesis of cytokines in placental DT. The content of cytokines in extracts of DT allows us to assess the possibility of manifestation of their immunoregulatory properties at a local level in the placenta. This is due to the fact that DT plays an important regulatory role and is a place of immigration, development and functioning of unique subpopulations of lymphocytes, natural killer cells (EC). The increased local level of cytokines produced by large granular lymphocytes serves as a growth factor for trophoblast.

With an increase in the severity of anemia, the production of the studied systemic cytokines and lactoferrin increases (Table 1). So, in the group of pregnant women with moderate anemia, the level of IL- $1 \beta$ increased by 1.2 times $(256,1 \pm 15,9 \mathrm{pg} / \mathrm{ml}, \mathrm{p}<0.05)$ compared to the control values $(211,3 \pm 12,8 \mathrm{pg} / \mathrm{ml})$, and IL-6 by 1.3 times $(113,3 \pm 7,4 \mathrm{pg} / \mathrm{ml}$ than $87,9 \pm 8,1 \mathrm{pg} / \mathrm{ml}, \mathrm{p}<0.05)$. The concentration of TNF- $\alpha$ and IL- 8 exceeded the corresponding parameter of the control group by $1.4(82,6 \pm 5,9 \mathrm{pg} / \mathrm{ml}$ than $59,9 \pm 3,7 \mathrm{pg} / \mathrm{ml})$ and 1.9 times $(70,1 \pm 5,8 \mathrm{pg} / \mathrm{ml}$ than $36,1 \pm 3,3 \mathrm{pg} / \mathrm{ml})$, respectively $(\mathrm{p}<0.05)$. The level of lactoferrin was 1.3 times significantly higher $(1354,1 \pm 86,6 \mathrm{ng} / \mathrm{ml})$ than the control indicator $(1028,8 \pm 80,1 \mathrm{ng} / \mathrm{ml}, \mathrm{p}<0.05)$.

With increasing severity of anemia, the local cytokine immune response (Table 2) is characterized by an increase in the synthesis of pro-inflammatory cytokines: a gradual significant increase in the concentration of TNF- $\alpha(114,2 \pm 7,2 \mathrm{pg} / \mathrm{ml}$ than $88,7 \pm 6,2 \mathrm{pg} / \mathrm{ml})$, IL$1 \beta(317,1 \pm 21,7 \mathrm{pg} / \mathrm{ml}$ than $255,8 \pm 15,4 \mathrm{pg} / \mathrm{ml})$, IL-6 $(263,2 \pm 19,3 \mathrm{pg} / \mathrm{ml}$ than $212,5 \pm 14,4 \mathrm{pg} / \mathrm{ml})$ and IL- $8(84,5 \pm 4,7 \mathrm{pg} / \mathrm{ml}$ than $48,5 \pm 4,3 \mathrm{pg} / \mathrm{ml}$ ) is $1,3,1.2$ and 1.7 times $(p<0.05)$, lactoferrin secretion increases 1.36 times $(988,3 \pm 37,6 \mathrm{ng} / \mathrm{ml}$ than $724,9 \pm 50,3 \mathrm{ng} / \mathrm{ml}, \mathrm{p}<0.05)$. This can lead to the development of necrosis at the site of introduction of trophoblast into the decidual membrane.

In pregnant women with anemia and preeclampsia, the entire cascade of pro-inflammatory cytokines is launched, the high concentration of which is an unfavorable factor reflecting the activity and severity of the pathological process (Table 1). So, in women with preeclampsia and mild anemia, the level of IL-1 $\beta$ is 1.5 times higher than the control values $(317,3 \pm 14,2 \mathrm{pg} / \mathrm{ml}$ than $211,3 \pm 12,8 \mathrm{pg} / \mathrm{ml}$, $\mathrm{p}<0.01)$. Moreover, to the maximum degree (1.9 times), these changes were noted in women with preeclampsia against the background of moderate anemia $(397,9 \pm 17,9 \mathrm{pg} / \mathrm{ml}$ than $211,3 \pm 12,8 \mathrm{pg} / \mathrm{ml} \mathrm{p}<0.001)$. Our results are consistent with those of Y. C. Casart et al., ${ }^{16}$ LaMarca B. et al., ${ }^{20}$ which in pregnant women with preeclampsia also noted an increase in the pro-inflammatory cytokines IL- 6 , IL-1 $\beta$ in the blood serum.

With an increase in the severity of anemia in pregnant women with preeclampsia, there is also a significant increase in the content of IL - 6 in the blood serum $(162,2 \pm 8,5 \mathrm{pg} / \mathrm{ml}$ than $87,9 \pm 8,1 \mathrm{pg} / \mathrm{ml})$ and decidual placental tissue $(323,9 \pm 14,8 \mathrm{pg} / \mathrm{ml}$ than $212,5 \pm 14,48 \mathrm{pg} /$ $\mathrm{ml}$ ) of mild anemia in relation to the control values of 1.8 and 1.5 times $(p<0.05)$ and in pregnant women with moderate anemia in the blood serum $(219,3 \pm 9,9 \mathrm{pg} / \mathrm{ml}$ than $87,9 \pm 8,1 \mathrm{pg} / \mathrm{ml}, \mathrm{p}<0.05)$ and in DT $(437,4 \pm 25,4 \mathrm{pg} / \mathrm{ml}$ than $212,5 \pm 14,4 \mathrm{pg} / \mathrm{ml})$-of $2.5-2.1$ times $(p<0.05)$, respectively, which indirectly indicates a pronounced local inflammatory process associated with the severity of the pathology. It was found that in the main group of pregnant women with preeclampsia there is a significant increase in the production of serum IL-8 in 2.63.4 times $(94,7 \pm 5,7 \mathrm{pg} / \mathrm{ml}$ and $120,8 \pm 9,2 \mathrm{pg} / \mathrm{ml}$ than $36,1 \pm 3,3 \mathrm{pg} / \mathrm{ml}$, $\mathrm{p}<0.001)$, as well as decidual cells in 2.7-3.6 times $(129,5 \pm 8,1 \mathrm{pg} / \mathrm{ml}$ and $175,8 \pm 12,8 \mathrm{pg} / \mathrm{ml}$ than $48,5 \pm 4,3 \mathrm{pg} / \mathrm{ml}, \mathrm{p}<0.001$ ) respectively of mild and moderate IDA. The data obtained on the increase in IL-1 $\beta$ and IL- 8 is a reflection of the activity of the inflammatory process.

An analysis of immunological imbalance showed a direct correlation with the severity of the pathological process, which indicates the significant role of pro-inflammatory cytokines in the pathogenesis of preeclampsia.

In pregnant women with preeclampsia and mild anemia, the serum TNF- $\alpha$ level increases by 1.45 times $(86,7 \pm 5,6 \mathrm{pg} / \mathrm{ml}$ than $59,9 \pm 3,7 \mathrm{pg} /$ $\mathrm{ml}$ ), and with preeclampsia and moderate anemia increases by 1.9 times $(113,2 \pm 6,5 \mathrm{pg} / \mathrm{ml}$ than $59,9 \pm 3,7 \mathrm{pg} / \mathrm{ml}-\mathrm{p}<0.001)$. In comparing with the data of the control group and the previous two groups: by 1.4 times (than $82,6 \pm 5,9 \mathrm{pg} / \mathrm{ml}-\mathrm{p}<0.01$ ) and by 1.3 times (than $86,7 \pm 5,6 \mathrm{pg} / \mathrm{ml}-\mathrm{p}<0.01)$. In preeclampsia in placental decidual tissue the TNF- $\alpha$ level was 1.4 and 1.5 times higher than the control group $(121,4 \pm 7,4 \mathrm{pg} / \mathrm{ml}$ and $130,4 \pm 7,6 \mathrm{pg} / \mathrm{ml}$ than $88,7 \pm 6,2 \mathrm{pg} / \mathrm{ml}, \mathrm{p}<0.01)$. It can be assumed that an increased level of TNF- $\alpha$ may contribute to the pathogenesis of preeclampsia.

In women with preeclampsia and mild anemia the increased concentration of lactoferrin was observed: the serum concentration was 1.5 times higher than in women without preeclampsia $(1565,5 \pm 80,3 \mathrm{ng} / \mathrm{ml}$ than $1028,8 \pm 80,13 \mathrm{ng} / \mathrm{ml})$ and 1.7 times higher with preeclampsia and moderate anemia $(1750,9 \pm 71,58 \mathrm{ng} / \mathrm{ml}$ than $1354,1 \pm 86,6 \mathrm{ng} / \mathrm{ml})$, the local level in the decidual membrane of the placenta significantly exceeded normative indicators 1.8 and 1.9 times $(1279,7 \pm 51,0 \mathrm{ng} / \mathrm{ml}$ than $724,9 \pm 50,3 \mathrm{ng} / \mathrm{ml}$ and $1371,9 \pm 50,9 \mathrm{ng} / \mathrm{ml}$ than $724,9 \pm 50,3 \mathrm{ng} / \mathrm{ml}, \mathrm{p}<0.05)$.

Thus, as our studies have shown, preeclampsia on the background of IDA is accompanied by an increased level of proinflammatory cytokines and an acute phase protein - lactoferrin at the systemic and local level. Moreover, these changes are most pronounced in the decidual membrane of the placenta with the development of preeclampsia against the background of moderate anemia.

The presence of a strong positive correlation between an increase in the levels of TNF- $\alpha$, IL-1 $\beta$, IL- 6 , IL- 8 and the clinical condition of the pregnant women examined by us indicates significant violations in which cytokines penetrate the systemic circulation, which contributes to pathogenesis preeclampsia, which developed against a background of chronic anemia. Changes in the cytokine status (TNF- $\alpha$, IL-1 $\beta$, IL-6, and IL-8) both systemically and locally once again confirm the participation of the immune system in the pathogenesis of preeclampsia, one of the triggers of which is immune imbalance in iron deficiency anemia.

Thus, our results of the study suggest that excessive stimulation of the systemic and local humeral immune response is one of the fundamental mechanisms underlying the development of preeclampsia against the background of iron deficiency anemia. 


\section{Discussion}

The placenta produces a large number of hormones and acts as an immunological barrier, synthesizing immunosuppressive factors, which creates immunologically privileged conditions for the development of the fetus. Activation of pro-inflammatory cytokines occurs with progesterone deficiency. Under the influence of proinflammatory cytokines, primary placental insufficiency is formed. Placental dysfunction, in particular, increased apoptosis plays a role in the pathogenesis of the formation of preeclampsia, ${ }^{23-25}$ while Fas-mediated apoptosis may be involved in creating conditions for abnormal placentation leading to preeclampsia. ${ }^{26}$ Preeclampsia is associated with systemic inflammation and damage to trophoblast invasion into the decidual uterine membrane. Macrophage infiltration is involved in damage to trophoblast invasion, leading to the development of preeclampsia. We believe that preeclampsia could be associated with an increase in decidual dendritic cell infiltration and that IL- $1 \beta$ increases the production of dendritic cell-mediated chemokinesis. It has been suggested that dendritic cells may play a decisive role in the pathogenesis of preeclampsia. ${ }^{17,27}$

Based on the research and literature data, we concluded that from the immunological position of the pathogenesis of preeclampsia, it is necessary to review some issues of therapy. One of the directions in the treatment of preeclampsia should be therapy aimed at reducing the inadequate immune response of the mother's body to paternal antigens of the embryo. In this regard, data of interest is that in pregnant women who received duphaston from the first weeks of pregnancy, gestosis (preeclampsia) was much less common, ${ }^{28}$ which indicates the role of the maternal body's immune response in the development of complications of gestation processes. Pathogenetically substantiated is the use of placental hormone progesterone. The role of progesterone deficiency in the development of preeclampsia is presented as follows. From the literature it follows that the leading role is assigned to decidual natural killers (EC) cells that supply the factors necessary for the development and vascular changes in the feto-placental system, and they can play a leading role in the development of preeclampsia. ${ }^{27,29}$ Thus, it was found that the progesterone-induced blocking factor, acting on zero (NK) cells, directs the mother's immune response to the embryo towards less active NK cells carrying markers CD 56+, CD 16+. In the presence of these cells, the mother's immune response will be realized through type II T-helpers that produce regulatory cytokines (IL-3, IL-4, IL-10, IL-13).

With a lack of a progesterone induced blocking factor, the mother's immune response to trophoblast is shifted towards the lymphokines of activated killers that carry the markers CD 56+, CD 16+, and the mother's immune response is shifted towards a more active response through type $1 \mathrm{~T}$-helpers with the production of pro-inflammatory cytokines (TNF- $\alpha$, IL-1 $\beta$, IL-6). Violation of the Th1/Th2 balance against the background of a high functional (proliferative) reactivity of circulating $\mathrm{T}$ - lymphocytes and a quantitative deficit of natural regulatory $\mathrm{CD} 4+, \mathrm{CD} 25+\mathrm{T}$ - cells with suppressor activity may indicate a high risk of severe preeclampsia. ${ }^{30}$ However, it should be noted that this study was carried out on a rather limited population of 96 pregnant women with IDA, including 54 patients with preeclampsia, but the results were statistically highly reliable.

\section{Conclusion}

Thus, our data on the imbalance of the cytokine status at the systemic level indicate a malfunctioning immune response of the mother to the antigens of the ovum against the background of rearrangement of the endocrine system and iron deficiency anemia, which is one of the main causes of preeclampsia. High activation of pro-inflammatory cytokines at the site of attachment of the placenta can be considered a threat of allograft rejection, clinically manifested by premature placental abruption / preterm delivery, the most common complications of preeclampsia.

From this perspective, our study of the cytokine status during pregnancy can be of great interest in terms of substantiating new immunotherapy strategies in pregnancy complicated by preeclampsia. Clinical use of progesterone as an immuno suppressor and regulator of immune disorders from early pregnancy in women at high risk of developing preeclampsia (including IDA patients) can significantly reduce cases of developing preeclampsia.

\section{Acknowledgments}

None.

\section{Funding}

The authors of this article confirm the lack of financial or any other support that needs to be reported.

\section{Conflicts of interest}

The authors confirm the absence of any other conflict of interest that needs to be reported.

\section{References}

1. Dobrokhotova Yu E, Bakhareva IV. Iron deficiency anemia: prevention and treatment at pregnancy. Lechebnoe delo. 2016;3:4-13.

2. Breymann C, Honegger C, Hösli I, et al. Diagnosis and treatment of iron deficiency anaemia in pregnancy and postpartum. Archives of Gynecology and Obstetrics. 2017;296(6):1229-1234.

3. Bakhareva IV. Prevention and treatment of anaemia of pregnant women: results of use of vitamin-mineral complexes (according to the Russian Multi-Center Non-Investment Program "PROGNOSTIC"). Rossijskij vestnik akushera-ginekologa. 2017;17(3):66-73.

4. Suleimanova DN, Saidov AB, Normetova MU, et al. Modern aspects of parenteral use of iron preparations in clinical practice: methodological manual. Tashkent. 2018. 32 p.

5. Vinogradova MA. Iron deficiency anemia during pregnancy: features of therapy. Medicinskij sovet. 2017;20:194-197.

6. Radzinsky VE, Ordiyantz IM, Pobedinskaya OS. Iron deficiency anemia as a risk factor for placental insufficiency and perinatal complications. Akusherstvo i ginekologiya. 2016;12:125-130.

7. Abu-Ouf NM, Ja MM. The impact of maternal iron deficiency and iron deficiency anemia on child's health. Saudi Med J. 2015;36:(2):146-149.

8. Frass KA. Postpartum hemorrhage is related to the hemoglobin levels at labor: Observational study. Alexandria Journal of Medicine. 2015;51(4):333-337.

9. Goudar SS, Carlo WA, McClure EM, et al. The maternal and newborn health registry study of the global network for women's and children's health research. Int J Gynaecol Obstet. 2012;118(3):190-193.

10. Tandu-Umba B, Mbangama AM. Association of maternal anemia with other risk factors in occurrence of Great obstetrical syndromes at university clinics Kinshasa, DR Congo. BMC Pregnancy Childbirth. $2015 ; 15: 183$. 
11. Djabbarova Yu K, Malikova GB. Iron deficiency anemia in obstetrics and gynecology: Methodological recommendations for doctors. Tashkent. 2011.

12. Yusupov UY, Mirzayeva A, Yuldashev RS. Anemia of severe degree as a factor of development of obstetric complications. VI congress of Obstetricians-Gynaecologists of the Republic of Uzbekistan, Tashkent. Vestnik vracha obshej praktiki; 2003:116-119.

13. Abdullayeva NK. Neuroimmune aspects of preeclampsia. Rossijskij vestnik akushera-ginekologa. 2014;5:18-21.

14. Demchenko OB. Preeclampsia as a problem of modern obstetrics. 2018.

15. Erzhan ZE, Raeva RM, Moshkalova GN, et al. Severe preeclampsia is an actual problem of modern obstetrics. Vestnik Kazahstanskogo nacionalnogo medicinskogo universiteta. 2013;4(1):33-35.

16. Casart Y, Tarrazi K, Camejo M. Serum levels of interleukin-6, interleukin-1 beta and human chorionic gonadotropin in pre-eclamptic and normal pregnancy. Ginec Endocr. 2007;23(5):300-320.

17. Huang SJ, Chen CP, Schatz F, et al. Pre-eclampsia is associated with dendritic cell recruitment into the uterine decidua. J Pathol. 2008; 214(3):328-336.

18. Sidorova IS, Nikitina NA. Prospects for treatment of preeclampsia. Akusherstvo i ginekologiya. 2018;6:5-10.

19. Schifman EM. Immunological aspects of preeclampsia and promising directions of intensive care and prevention.

20. LaMarca B, Brewer J, Wallace K. IL-6-induced pathophysiology during pre-eclampsia: potential therapeutic role for magnesium sulfate? Lancet. 2011;3:59-64.

21. Smorkalova EV, Nikulicheva VI, Safuanova G. Sh Citokines - negative regulators of gemopoez at iron deficiency anemia. Health of family - the 21st century: materials XXIII of the international conference; 2009:337340 .
22. Dubrovina NV, Tyutyunnik VL, Kan NE, et al. Iron deficiency anaemia in pregnant women and maternity women - a choice of drugs for treatment. Medicinskij sovet. 2016;2:35-40.

23. Suhih GT, Krasnyj AM, Kan NE, et al. Apoptosis and expression of antioxidant protection enzyme genes in placenta in preeclampsia. Akusherstvo i ginekologiya. 2015;3:11-15.

24. Dolgushina VF, Syundyukova EGO. Substance of placental apoptosis and cell proliferation in preeclampsia. Akusherstvo $i$ ginekologiya. 2015;2:12-19.

25. Hovhayeva PA, Krasnyj AM, Tyutyunnik NV, et al. Apoptosis in placenta at preeklampsiya. Medicinskij sovet. 2016;2:102-103.

26. Neale DM, Mor G. The role of Fas mediated apoptosis in preeclampsia. $J$ Perinat Med. 2005;33:(6):471-477.

27. Selkov SA, Sokolov DI. Immunological mechanisms for control of placenta development. Zhurnal akusherstva i zhenskih boleznej. 2010;LIX (1):6-10.

28. Doschanova AM. Gestosis-as a reflection of the immune response of the mother's body to the developing fetus egg. VI congress of ObstetriciansGynaecologists of the Republic of Uzbekistan, Tashkent. Vestnik vracha obshej praktiki; 2003;2:3-4.

29. Goldman-Wohl D, Yagel S. NK cells and pre-eclampsia. Reprod Biomed Online. 2008;16(2):227-231.

30. Seledtsova NV, Honina NA, Tihonova MA, et al. T-cell immunity parameters in pregnant women with normal and elevated serum dehydroepiandrosterone sulfate. Medicinskaya immunologiya. Days of Immunology in Sankt-Piterburg. 2006;8(2-3):319-320. 